\title{
Identification, Occurrence, and Distribution of Strains Sugarcane Mosaic in Puerto Rico
}

\author{
G. W. Bruehl $l^{1}$
}

\section{INTRODUCTION}

Many aspects of the mosaic disease were studied in Puerto Rico in the pioneering efforts following the mosaic epidemic of 1916-19 (13). ${ }^{2}$ Control measures were successfully applied as knowledge and understanding of this disease increased. Research upon mosaic diminished when the press of necessity lessened. Mosaic has been present constantly in parts of Puerto Rico since its introduction, maintained in a small percentage of infected plants in B. H. 10(12), and in scattered stools of P.O.J. 36, D. 1135, and probably in other susceptible varieties occurring as unnoticed remnants among resistant canes in mixed plantings. Many grasses other than sugarcane are susceptible (15) and could serve as reservoirs of the virus, but observations indicate that mosaic does not survive long in grasses here. B. 34104 was recently propagated extensively on the lowlands of the southcentral and south-eastern sections of the Island, in contact with B.H. 10(12), and from there has spread to smaller plantings in many localities. This variety was quickly infected (7); and the infection is spreading in $\mathrm{M}$. 336 (4) and B. 37161. The resurgence of mosaic from a minor, controlled disease to a spreading major problem has stressed the need for further research.

\section{REVIEW OF THE LITERATURE}

In an extensive breeding program adequate testing for disease resistance is aided by a knowledge of the presence or absence of strains of the pathogen, and studies on the most practical methods of inoculation in various stages of selection. Summers (14) pioneered in the identification of strains of the mosaic virus in Louisiana, and eventually (15) several strains, differing in virulence, infectivity, and type of symptoms produced on certain differential varieties, were described. Abbott (3) reported differences in the

1 Plant pathologist, Sugar Plant Investigations, Agricultural Research Service, United States Department of Agriculture, in cooperation with the Agricultural Experiment Station, University of Puerto Rico, Río Piedras, P. R. The author wishes to express his gratitude for the counsel of Dr. E. V. Abbott, U.S.D.A. Sugar Plant Experiment Station, Houma, La., and for the cooperation of many individuals and agencies in the collection of mosaic-infected canes, and particularly Mr. P. GonzálezRíos, Head, Department of Plant Breeding, Agricultural Experiment Station, Río Piedras, P. R.

2 Numbers in parentheses refer to Literature Cited, p. 197-8. 
ability of some of these strains to withstand heat and dilution. Knowledge of strains of mosaic in Puerto Rico dates from the interception of strain B on B.H. 10(12) from Puerto Rico in the quarantine houses in Arlington Farm, Va. (11). Jensen (8) observed synaptoms in commercial fields suggesting the presence of two or more strains.

Bruehl (5) identified strains apparently identical with those described by Summers. The completion of the strain survey of $1952-53$ is presented in this paper. The potential severity of mosaic in continental United States with its several virulent strains of the mosaic virus has led to the general use of the inoculation of very young seedlings with juice and carborundum (1), and the immediate rejection of all plants showing symptoms subsequent thereto. This technique was used on 8,000 seedlings of the 1953 crosses and was considered successful. Both the Seín (12) and Matz (10) methods were tried on plants grown from cane pieces.

\section{MATERIALS AND METHODS}

Canes from infected plants were selected from fields in as many locations and planted to as many varieties as possible. These canes, comprising a sample of the mosaic virus in Puerto Rico, were brought to Río Piedras where they were propagated and grown until sufficient leaf material was formed to permit juice extraction and inoculation. The differential varieties (15) C.P. 31/294 and C.P. 29/291 were used to screen the collection.

Five 6-inch standard pots of each variety with two single-eye seed pieces were planted for each collection. The number of plants of each differential variety for inoculation with each collection varied from 5 to 10 , depending upon germination.

The test plants were inoculated when 7 to 9 inches tall. They received applications of nitrogen 3 days prior to and about 1 week after inoculation, along with frequent watering, to keep them in a condition of rapid growth conducive to quick and clear symptom expression. A drop of juice from young leaf material was placed deep in the whorl of unfolding leaves. A thin steel insect-mounting pin was thrust repeatedly through the infectious juice and enclosing leaf tissues (10). The inoculated plants were grown in the greenhouse interspersed with uninoculated check plants. No check plants developed mosaic. Observations on mosaic type were made 6 to 8 weeks after inoculation. The system of classification used in Louisiana (15) was followed.

Selected collections were further tested on Co. 281. The commercial varieties M. 336, H. 328560 , B. 37161, B. 34104, and B.H. 10(12) were inoculated with samples of all types of mosaic found to determine whether they had value as differential hosts. 


\section{RESULTS \\ IDENTIEICATION OF STRAINS}

Most of the collections were grouped into strains A, B, and D, as described by Summers. The scope of this work was exploratory, extensive rather than intensive. Identification of strains by symptoms alone is somewhat subjective. Gradations and variations occur in a large number of collections. Broad limits of distinction were used. More precise techniques and more differentials might have resolved the collections into a greater number of groupings.

Strain A caused a mild mottling on the leaves of C.P. 31/294, with no necrosis, and only rarely a few chlorotic lesions. It did not stimulate tiller formation, was moderately stunting, and was easily transmitted.

Strain B formed many fine, elongate, strongly chlorotic-to-white lesions on leaves of C.P. 31/294, a variable amount of reddish necrosis which was seldom severe, caused moderate to severe stunting, and frequently produced excessive tillering. When healthy plants of the same' age had no tillers, many of those infected with strain B would have 5 to 6 . Some plants died. In general the internodes of severely affected plants were so shortened that the leaves appeared to rise immediately above one another. This type was highly infectious.

Strain D was most easily distinguished about 6 weeks after inoculation. Lesions apparently devoid of chlorophyll, longer and ferver in number than in type B, typified this strain. The background green or 'unaffected' leaf tissue was darker than that of healthy plants, resulting in a strong contrast between the whitish lesions and surrounding tissues. A variable amount of reddish-purple necrosis occurred with some collections, and tiller formation was moderately stimulated in a few. It was only poorly to moderately infectious. What was a clear type-D collection would frequently undergo a deterioration into a 'mixture' more like type A after 2 or more months on C.P. 31/294. This instability of strain D on C.P. 31/294 has been observed elsewhere (2). The Puerto Rican collections of strain D seemed less virulent than those of continental United States.

Leaf-sheath blotches were formed in variable degree on C.P. 29/291 in all but two collections. One formed type-B lesions on C.P. 31/294 and thus would correspond to Summers' strain G, and the other was an A on C.P. $31 / 294$, making it an undescribed type. A variation in strain A was noted, in that a few collections brought an excessive expansion of the leaf blade near its junction with the sheath, folding troughlike upwards, with more severe stunting. These anomalies were not studied further as they were rare occurrences. No type-C lesions were observed on any inoculations to Co. 281. None of the commercial varieties used showed differential symptoms. 
- TABle 1.-Strains of mosaic observed on C.P. 31/294 and C.P. 29/291 approximately 60 days after inoculation ${ }^{1}$

\begin{tabular}{|c|c|c|c|c|c|}
\hline \multirow{2}{*}{$\begin{array}{l}\text { Origin of collection by locality and } \\
\text { variety }\end{array}$} & \multicolumn{4}{|c|}{ Strain identification } & \multirow{2}{*}{ Total } \\
\hline & A & B & $\mathrm{D}$ & Unidentified & \\
\hline \multicolumn{6}{|l|}{ Locality: } \\
\hline Yabucoa & 0 & 29 & 5 & 3 & 37 \\
\hline Humacao & 3 & 7 & 2 & 2 & 14 \\
\hline Naguabo & 0 & 0 & 1 & 0 & 1 \\
\hline Ceiba & 0 & 4. & 3 & 0 & 7 \\
\hline Fajardo & 0 & 1 & 0 & 0 & 1 \\
\hline Juncos & 2 & 1 & 1 & 0 & 4 \\
\hline San Lorenzo & 0 & 0 & 3 & 0 & 3 \\
\hline Gurabo & 0 & 3 & 6 & 0 & 9 \\
\hline Caguas & 1 & 7 & 5 & 6 & 19 \\
\hline Cayey & 0 & 0 & 1 & 0 & 1 \\
\hline Patillas & 2 & 4 & 0 & 0 & 6 \\
\hline Arroyo & 1 & 3 & 0 & 0 & 4 \\
\hline Aguirre & 2 & 7 & 2 & 2 & 13 \\
\hline Cortada & 5 & 6 & 5 & 3 & 19 \\
\hline Mercedita & 5 & 23 & 3 & 0 & 31 \\
\hline Tallaboa & 0 & 3 & 0 & 0 & 3 \\
\hline Hormigueros & 0 & 7 & 0 & 0 & 7 \\
\hline Añasco & 0 & 2 & 1 & 0 & 3 \\
\hline Coloso (all P.O.J. 36) & 0 & 7 & 0 & 0 & 7 \\
\hline Moca (all P.O.J. 36) & 0 & 19 & 0 & 0 & 19 \\
\hline Hatillo (all D. 1135) & 10 & 12 & 3 & 0 & 25 \\
\hline Manatí & 0 & 3 & 2 & 2 & 7 \\
\hline Vega Alta & 0 & 0 & 1 & 0 & 1 \\
\hline Loiza & 0 & 3 & 0 & 0 & 3 \\
\hline Total & 31 & 151 & 44 & 18 & 244 \\
\hline \multicolumn{6}{|l|}{ Variety: } \\
\hline B. $34: 104$ & 8 & 33 & 12 & 8 & 61 \\
\hline B.H. $10(12)$ & 4 & 28 & 6 & 3 & 41 \\
\hline B. 37161 & 5 & 12 & 13 & 2 & 32 \\
\hline M. 336 & 1 & 21 & .7 & 1 & 30 \\
\hline P.O.J. 36 & 0 & 29 & 0 & 0 & 29 \\
\hline D. 1135 & 10 & 12 & 3 & 0 & 25 \\
\hline B. 4098 & 0 . & 7 & 1 & 0 & 8 \\
\hline B. 41211 & 3 & 3 & 2 & 0 & 8 \\
\hline Unknown (Gurabo) & 0 & 3 & 0 & 2 & 5 \\
\hline H. 328560 & 0 & 2 & 0 & 1 & 3 \\
\hline P.O.J. 2878 & 0 & 1 & 0 & 0 & 1 \\
\hline Total & 31 & 151 & 44 & 18 & 244 \\
\hline
\end{tabular}

186 collections studied Feb.-May, 1953, and 158 studied Aug.-Dec., 1953. 
OCCURRENCE OF STRAINS A, B, AND D

Geographic distribution of the strains was more or less random, in contrast to the well-marked distribution found in Louisiana (15). The small area of Puerto Rico with its free interchange of seed cane may contribute to this situation. Vector preferences might also influence strain distribution. There seemed to be a greater concentration of strain D in the Inland area about Caguas, Gurabo, and San Lorenzo (table 1). In most places strain B predominated, but all three strains were well represented at Cortada.

Strain B was most abundant in the susceptible commercial varieties B.H. 10(12), B. 34104, and M. 336, while in B. 37161 strain D was equally well represented (fig. 1). P.O.J. 36 and D. 1135, no longer commercial canes

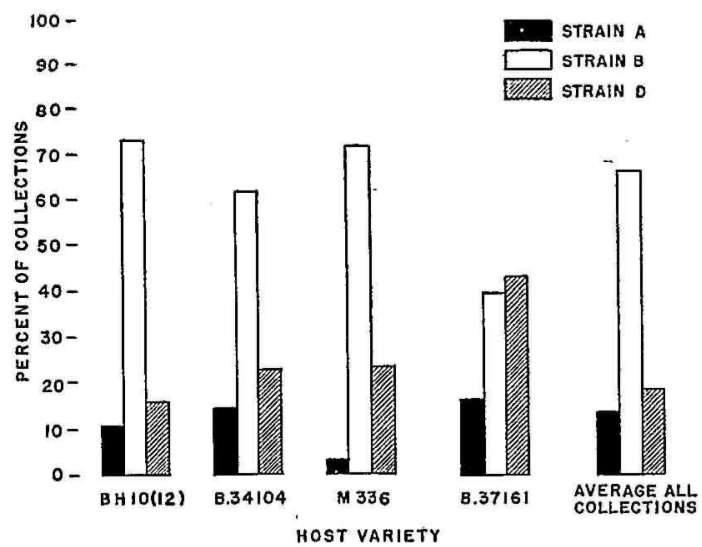

Frg. 1.-Distribution of strains of the mosaic virus in major varieties in Puerto Rico, 1952-53.

TABLE 2.-Influence of source (host variety) of the mosaic virus (strain B) upon virulence and variability of collections judged by their effect on C.P. 31/294

\begin{tabular}{l|c|c|c|c|c}
\hline \multicolumn{1}{c|}{ Variety } & $\begin{array}{c}\text { Collections } \\
\text { compared }\end{array}$ & Mean height, & Variance & $\begin{array}{c}\text { Standard } \\
\text { deviation }\end{array}$ & $\begin{array}{c}\text { Coefficient of } \\
\text { variation }\end{array}$ \\
\cline { 1 - 2 } Number & Inches & & & & Percent \\
B. 37161 & 5 & 41.5 & 48.35 & 6.95 & 16.7 \\
B.H. 10(12) & 17 & 40.4 & 23.94 & 4.89 & 12.1 \\
B. 34104 & 11 & 38.7 & 20.98 & 4.58 & 11.8 \\
M. 336 & 19 & 38.1 & 32.14 & 5.67 & 14.9 \\
P.O.J. 36 & 20 & $34.8^{2}$ & 8.09 & 2.84 & 8.2 \\
\hline
\end{tabular}

${ }^{1}$ Plant height $=$ ground line to tip of longest leaf.

2 The collections from P.O.J. 36 shortened C.P. 31/294 in comparison with those from M. 336 and B. 34104 at the 5-percent level of significance, and from B.H. 10(12) and B. 37161 at the 1-percent level. 
were found infected and growing in isolation from new sources of mosaic as remnant stools in large areas of highly resistant canes. They are of greatest interest as historical specimens. Strains A, B, and D were recovered from D. 1135, and only strain B from P.O.J. 36.

Strain B makes up the bulk of the mosaic in Puerto Rico at the present time, with $\mathrm{A}$ and $\mathrm{D}$ present to a lesser extent (table 1). Considerable variability was observed among the 151 collections of strain $\mathrm{B}$. The accessions

TABLE 3.-Composite reaction of varieties of sugarcane to inoculation with mosaic virus strains $A, B$, and $D$, by the Matz method

\begin{tabular}{|c|c|c|}
\hline Variety 1 & Plants inoculated & Plants infected \\
\hline & Number & Percent \\
\hline B. 4098 & 34 & 94 \\
\hline B. 34104 & 114 & 92 \\
\hline B. 41211 & 34 & 91 \\
\hline B.H. 10(12) & 114 & 89 \\
\hline B. 40116 & 26 & 81 \\
\hline M. 336 & 96 & 77 \\
\hline B. 40105 & 27 & 70 \\
\hline H. 328560 & 103 & 60 \\
\hline B. 37161 & 101 & 59 \\
\hline M. 341 & 37 & 51 \\
\hline P.R. 968 & 28 & 46 \\
\hline H. 371933 & 16 & 44 \\
\hline M. $32-134^{1}$ & 31 & 29 \\
\hline P.R. 970 & 24 & 25 \\
\hline Co. 421 & 29 & 21 \\
\hline P.O.J. 2725 & 32 & 19 \\
\hline P.R. 967 & 24 & 13 \\
\hline P.R. 969 & 37 & 8 \\
\hline P.R. 902 & 27 & 7 \\
\hline P.R. 907 & 30 & 7 \\
\hline P.R. 999 & 29 & 7 \\
\hline B. 41227 & 30 & 3 \\
\hline P.R. 903 & 31 & 3 \\
\hline P.P.Q.K. & 30 & 0 \\
\hline B. 4362 . & 35 & 0 \\
\hline M. 28 & 29 & 0 \\
\hline M. 275 & 30 & 0 \\
\hline M. 317 & 37 & 0 \\
\hline M. 338 & 27 & $\mathbf{0}$ \\
\hline P.R. 905 & 35 & 0 \\
\hline P.R. 1000 & 20 & 0 \\
\hline P.O.J. 2878 & 34 & 0 \\
\hline
\end{tabular}

${ }^{1}$ M. 32-134 is a variety of Mauritius. All other M. varieties are from Mayagüez, P.R. B = Barbados; C.P. = Canal Point; H. = Hawaii; Co. = Coimbatore; P.O.J. $=$ Proefstation Oost Java; P.R. = Puerto Rico (Río Piedras). 
TABLE 4.-Field observations of mosaic on 5 commercial varieties of sugarcane, with inoculation results by the Matz and Sein methods being compared

\begin{tabular}{|c|c|c|c|c|c|c|c|c|c|}
\hline \multirow{4}{*}{ Variety } & \multicolumn{3}{|c|}{$\begin{array}{l}\text { Mosaic observed in com- } \\
\text { mercial fields in Puerto } \\
\text { Rico, Aug.-Sept. } 1952\end{array}$} & \multicolumn{6}{|c|}{ Mosaic induced by inoculation } \\
\hline & \multirow{3}{*}{$\mid \begin{array}{l}\begin{array}{l}\text { Fields } \\
\text { ob- } \\
\text { served }\end{array} \\
\text { Namber }\end{array}$} & \multirow{3}{*}{ 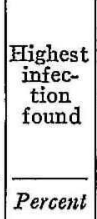 } & \multirow{3}{*}{$\begin{array}{c}\text { Average } \\
\text { infec- } \\
\text { tion in } \\
\text { all fields } \\
\text { ob- } \\
\text { served } \\
\\
\text { Percent }\end{array}$} & \multicolumn{3}{|c|}{$\begin{array}{l}\text { Results of inoculation by } \\
\text { Matz method }\end{array}$} & \multicolumn{3}{|c|}{$\begin{array}{l}\text { Results of inoculation by } \\
\text { Seín method }\end{array}$} \\
\hline & & & & \multirow{2}{*}{$\begin{array}{l}\begin{array}{c}\text { Plants } \\
\text { inocu- } \\
\text { lated }\end{array} \\
\text { Number }\end{array}$} & \multicolumn{2}{|c|}{ Plants infected } & \multirow{2}{*}{$\frac{\begin{array}{c}\text { Plants } \\
\text { inocu- } \\
\text { lated }\end{array}}{N_{\text {unber }}}$} & \multicolumn{2}{|c|}{ Plants infected } \\
\hline & & & & & Number & Percent & & Number & Percent \\
\hline B. 34104 & 19 & 95 & 38 & 114 & 105 & 92 & 92 & 64 & 69 \\
\hline B.H. 10(12) & 7 & 64 & 17 & 114 & 101 & 89 & 95 & 57 & 60 \\
\hline B. $37161^{1}$ & 14 & 8 & 2 & 101 & 60 & 59 & 96 & 33 & 34 \\
\hline M. $336^{1}$ & 17 & 3 & 0.2 & 96 & 74 & 77 & 101 & 35 & 35 \\
\hline Н. 328560 & 10 & 5 & 1 & 103 & 62 & 60 & 110 & 6 & 5 \\
\hline
\end{tabular}

1 Since the time of this survey higher field infections have been observed on $B$. 37161 and M. 336. Allowing for subsequent untabulated observations, the proper order of field susceptibility would be B. 34104, B.H. 10(12), B. 37161, and M. 336 , with H. 328560 being quite resistant.

from the commercial canes seemed more variable and, on the average, less virulent on C.P. 31/294 than those collected from D. 1135 and P.O.J. 36, and calculations ${ }^{3}$ confirmed this relationship (table 2 ).

\section{INOCULATION FXPPERIMENTS ON VARIOUS VARIETIES}

Several varieties were inoculated by the Matz method (10). This method of varietal testing was severe (table 3), as high percentages of infection were obtained in known susceptible varieties. Inoculation by this method was rapid and easily performed. Strain A was most infectious, B intermediate, and D least, with 59,50 , and 34 percent, respectively, of the plants that were inoculated becoming infected.

The Sein method (12) was given a small trial. It was less severe than the Matz method (table 4), and results were better correlated with observations of varietal susceptibility in the field. As in the Matz method, strain A was most infectious (66 percent), B intermediate (32 percent), and D least infectious (19 percent). The Seín method was comparatively laborious and slow.

\section{DISCUSSION}

The major strains of mosaic in Puerto Rico correspond closely to strains already described from continental United States. This indicates a degree

3 The inoculations were made over a period of time, and statistical treatment removing this effect was made by Mr. I. Bangdiwala. 
of basic stability in the mosaic virus, as the differences in climate and host varieties did not effect any major transformation in virus strains probably of the same origin. It may indicate that, although infinite minor variations occur within strains, there are fairly stable types adapted to widespread existence under field conditions, and that there is little danger of rapid development of new and devastating types as occurs in many other pathogens. The relative stability of the virus is supported by the continued success of Kassoer as a source of resistance. Continued care in the introduction of canes and closely related grasses should be practised, as not all known strains were found in Puerto Rico.

The mosaic collections on D. 1135 and P.O.J. 36 are of interest in that they allow historical deductions. The infected D. 1135 has grown continuously near Hatillo ${ }^{4}$ for over 30 years, completely, surrounded by resistant canes and free from any recent source of mosaic. The recovery of strains A, B, and D from this; source indicates that these three strains were established on the Island many years ago, and that no other strain has been established on any scale since.

P.O.J. 36 can also be traced back several years ${ }^{5}$ in isolation from new sources of mosaic. Only B was obtained from this cane. Matz (11) stated that P.O.J. 36 was one of the first mosaic-infected canes introduced into Puerto Rico from Java by way of Tucuman, Argentina. If the original seed was infected it is possible through protective exclusion (6) and failure to recover, that this mosaic has remained the same since its introduction. P.O.J. 36 could have given the dissemination of strain B considerable impetus.

The recent discovery of mosaic on M. 336 (4), a variety long considered resistant, led to the hypothesis that a new strain of mosaic might have developed. Juice taken from diseased D. 1135 and P.O.J. 36 and inoculated directly into M. 336 was highly infectious on this variety, indicating that M. 336 had previously escaped infection, though its infection required no change in the virus. The comparative uniformity and virūlence of collections of strain B from P.O.J. 36 and D. 1135 on C.P. 31/294 suggests that the isolation of these canes has perpetuated a single type while the other varieties have been infected by representatives of strain $\mathrm{B}$ of diverse origins, or that strain B has been modified in the other varieties and wider environmental conditions sampled in the commercial canes, generally toward less, virulent types.

\footnotetext{
${ }^{4} \mathrm{Mr}$. Rudolph Zequeira provided the history of these collections and assisted in the field of observations.

${ }^{5}$ P.O.J. 36 was collected on the west end of the Island, mostly at Coloso and Moca. Thanks are due to Mr. Alberto Esteves and Dr. J. B. Nolla for their assistance in collecting this cane.
} 
Assuming B.H. 10(12) was the major reservoir of inoculum, and that B. 34104, M. 336, and B. 37161 were infected from that source, B. 34104 and M. 336 were similar to B.H. $10(12)$ in reaction to strains, as they have not substantially changed the relative abundance of $A, B$, or $D$ from that found in B.H. 10(12). B. 37161, however, being exposed to the same inoculum, has altered the situation in that $\mathrm{D}$ is as abundant as $\mathrm{B}$ in that variety. B. 37161 apparently possesses some resistance to strain B, a big advantage when that is the prevalent strain. Strain D will tend to increase in B. 37161 , if it is not kept free from mosaic, and when this preferred strain is sufficiently abundant, mosaic may spread as rapidly in it as it did in B. 34104. This possibility should encourage growers to take all possible precautions to keep this valuable cane free from mosaic.

Mechanical transmission has certain limitations in determining the 'field reaction' of varieties exposed to an epidemic. Both Matz' and Seín's methods gave high infections on the susceptible canes B. 34104 and B.H. 10(12). Matz' method, however, gave 60-percent infection on H. 328560, a variety that to date has taken very little mosaic in the field. By Seín's method this variety was only 5-percent infected, and some resistance was indicated in B. 37161 and M. 336. As in Hawaii (9), fairly good correlation with observed field reaction was obtained by Seín's method. Matz' method was too severe to show gradations in susceptibility which had practical importance. P. R. 980 was observed with a moderate infection in a small field adjacent to diseased B. 34104, and P. R. 975 is susceptible when inoculated by the Matz method, but their field reaction to mosaic is not yet known. They should be propagated with caution where they will be exposed to mosaic.

Strain A was most infectious by both methods, of mechanical transmission, while B predominated in the field. Possibly the major vector or vectors of Puerto Rico transmit strain B more efficiently. It is important in planning programs of progeny testing to keep in mind that A was most easily transmitted mechanically, B intermediate, and strain D least transmissible.

\section{SUMMARY}

Three strains of sugarcane mosaic, A, B, and D, described in Louisiana, were found to make up the bulk of the collections of the sugarcane mosaic virus in Puerto Rico. Strain B was most prevalent. It was the major strain found on B.H. 10(12), B. 34104, and M. 336. Strain D was equally abundant on B. 37161 . B. 37161 showed some resistance to mosaic in the field as compared with B. 34104. This may be due to some resistance to strain B. If B. 37161 is not kept free of mosaic, the preferred strain D may in- 
crease in it and render it more susceptible in the field. No marked geographic pattern of strain distribution was observed.

Mechanical transmission of mosaic by the Sein method gave a better correlation with field reaction of varieties than did transmission by the Matz method. Strain A was most easily transmitted mechanically, while in the field strain B predominated in most varieties. Therefore, the vectors of Puerto Rico may be more efficient transmitters of strain B than of A.

\section{RESUMEN}

Tres cepas del mosaico de la caña de azúcar, A, B y D, descritas en Louisiana, se encontraron que comprendían el grueso de las colecciones del virus del mosaico en Puerto Rico. La cepa $B$ fué la que prevaleció más. Fué la cepa encontrada con mayor frecuencia en las variedades B. H. 10(12), B. 34104, y M. 336. En la variedad B. 37161 la cepa D fué igualmente abundante. La B. 37161 demostró cierta resistencia al mosaico en el campo, comparada con la B. 34104 . Puede que esto se deba a cierta resistencia al mosaico producido por la cepa B. Si la B. 37161 no se conserva libre del mosaico, la cepa preferida D puede aumentarlo en la variedad y hacerla más susceptible en el campo. No se observó un marcado patrón geográfico en la distribución de la cepa.

La trasmisión mecánica del mosaico, según el método Seín, dí una mejor correlación en las variedades en el campo que el método Matz. La cepa A pudo trasmitirse mecánicamente con mayor facilidad, mientras que en el campo la cepa B predominó en la mayor parte de las variedades, por lo tanto, puede que los vectores de Puerto Rico sean trasmisores más eficientes de la cepa B que de la A.

\section{LITERATURE GITED}

1. Abbott, E. V., Comparison of methods for artificially inoculating sugarcane seedlings with the mosaic virus, Phytopathol. 39 668-69 1949.

2. - Stability of strains of sugarcane mosaic virus, Phytopathol. 422811952 (Abst.).

3. - Tolerance to dilution and heat of six strains of the sugarcane mosaic virus, Proc. Int. Soc. Sugar Cane Tech., Eighth Congress, British West Indies, pp. 911-13, 1953.

4. Adsuar, José, Preliminary report of a mosaic disease of the resistant sugarcane variety Mayagüez-336, Tech. Paper 7, p. 9, illus., Agr. Exp. Sta., Univ. of P. R., 1950.

5. Bruehl, G. W., Strains of sugarcane mosaic in Puerto Rico, Plant Dis. Rptr., 37 (9) 1953.

6. Forbes, I. L., Immunity studies with sugarcane mosaic, Proc. Int. Soc. Sugar Cane Tech., Sixth Congress, Baton Rouge, La., pp. 566-72, 1938.'

7. González-Ríos, P., and Adsuar, J., Effect of mosaic on the yield of sugarcane variety B. 34104, J. Agr. Univ. P. R. 37(1) 13-8 1953. 
8. Jensen, J. H., The present sugarcane disease situation in Puerto Rico, Agr. Notes Mayagüez, P. R., No. 69, 1936.

9. Martin, J. P., and Carpenter, C. W., Testing cane varieties for disease resistance in Hawaii, Proc. Int. Soc. Sugar Cane Tech, Fifth Congress, Brisbane, Australia, 519-21, (illus.) 1935.

10. Matz, Julius, Artificial transmission of sugarcane mosaic, J. Agr. Res. 46 821-39 1933.

11. - Comparative study of sugarcane mosaic from different countries, Proc. Int. Soc. Sugar Cane Tech., Sixth Congress, Baton Rouge, La., 572-80, (illus.) 1938.

12. Seín, Jr., Francisco, Artificial transmission and other studies on sugarcane mosaic, Proc. Int. Soc. Sugar Cane Tech., Fourth Congress, San Juan, P. R., Bul. 84, 6p., 1932.

13. Stevenson, John A., The mottling or yellow stripe disease of sugar-cane. J. Dept. Agr. P. R. 3(3) 76 pp. (illus.) 1919.

14. Summers, Eaton M., Types of mosaic on sugar cane in Louisiana, Phytopathol. 24 1040-42, Abst., (illus.) 1934.

15. - - Brandes, E. W., and Rands, R. D., Mosaic of sugarcane in the United States, with special reference to strains of the virus, Tech. Bul. 955, U.S.D.A., 124 pp, illus., 1948. 